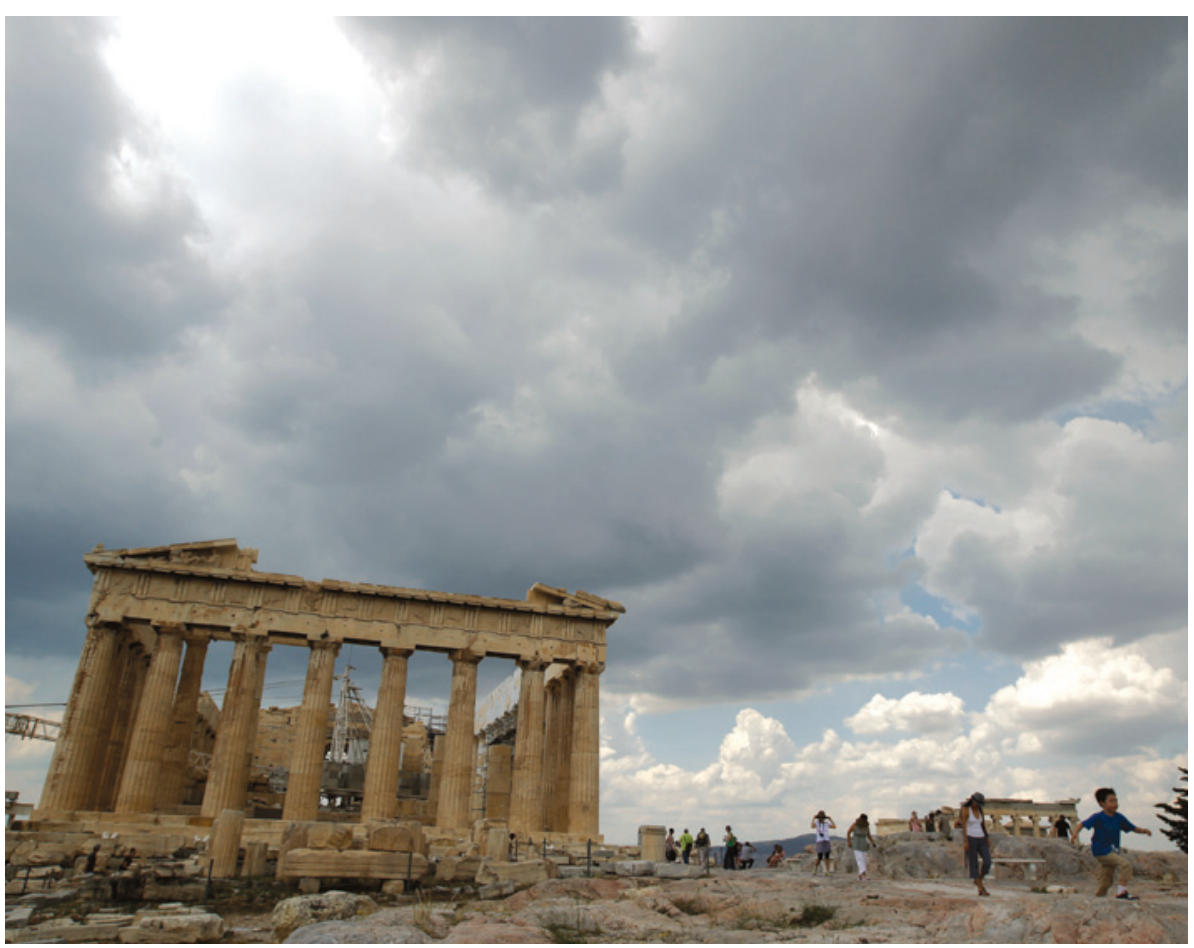

Unlike the Acropolis, many classical sites are under threat from looting.

\title{
ARCHAEOLOGY
}

\section{Cuts leave Greek heritage in ruins}

\section{Austerity measures damaging archaeological research.}

\section{BY LEIGH PHILLIPS}

$\mathrm{T}$ The economic and political turmoil in Greece is not just jeopardizing the country's economic future, it is also having a devastating effect on the country's rich cultural past, according to archaeologists in Athens.

Last month, the Association of Greek Archaeologists warned that the economic policies dictated by the European Union and the International Monetary Fund would cause "the destruction of both our country and our cultural heritage". The austerity measures intended to cut government debt have forced the state archaeological service to slash staff numbers by more than $10 \%$, with a further $35-50 \%$ reduction possible. Research and excavations are being abandoned. Museums that can no longer afford to pay for security are being plagued by armed robbers. And organized criminals are exploiting the chaos in an explosion of illegal digs and the trafficking of illicitly procured antiquities.

Despina Koutsoumba, president of the archaeologists' association, says that the

government no longer funds new research projects - other than those involving foreign partners to whom they are contractually obliged.

"Last year, a very important excavation underneath metro rail lines uncovered long walls connecting Athens to the port of Piraeus, built in the age of Pericles," she says. "The walls to the port were vital and played a major role in the Peloponnesian War as they linked Athens to the sea, and their strength was in their fleet." But the excavation was stopped uncompleted, she says, and there will be no opportunity to return to it once the rail lines are finished.

Koutsoumba says that the ministry also wanted to halt work at a site in Thessaloniki, after major buildings from the time of Roman emperor Gaius Galerius around AD 305-11 were discovered on land where a shopping centre was to be built. The archaeologists' associa-

ONATURE.COM

To read more on archaeology and ancient relics, see: go.nature.com/OygA10 tion won a small victory when it persuaded the ministry to continue the work, she says, "but it is a continuous struggle". Net salaries for young archaeologists in the service have been cut by $35 \%$, to $€ 670$ (US\$842) a month, and many have taken part-time jobs to supplement their income. Meanwhile, senior employees with the highest salaries and most experience are being forced into early retirement. Those who remain are reduced to bureaucratic 'box-ticking' - visiting construction sites to assess whether excavation is needed. They no longer have time for research or analysis, says Koutsoumba.

"Excavation is of course part of our job, but we also need time and funds to do research, to publish our findings. We are not giving anything to the scientific community and letting people know about our new discoveries - we are just digging up pretty objects," she says.

While legitimate archaeology is being hampered, looting is on the rise. The country is pockmarked with holes dug by the poor and desperate hoping for 'buried treasure', and organized criminals perform more professional excavations. "There is no doubt that there has been an increase in the past 3-4 years in both organized and amateur illegal digs and this is definitely related to the cuts," says Christos Tsirogiannis, a forensic archaeologist and researcher at the University of Cambridge, UK, who specializes in investigating the criminal networks behind trafficking in antiquities. $\mathrm{He}$ escorts the Greek police art squad on raids to identify looted antiquities.

"There is always a rise in this form of crime in regions rich with antiquities during times of crisis - in recent years in Egypt, Iraq and Afghanistan," says Tsirogiannis.

He says that auction houses and museums are not doing enough to avoid dealing in artefacts of "unprovenanced origin". "I wouldn't be surprised if in the coming years there is a large increase in the number of unprovenanced Greek antiquities sold openly," he says.

Christie's, the London auction house, has strict internal policies to ensure they only offer objects for sale legally, says Matthew Patton, head of communications.

The European Commission denies that spending cuts are to blame. "Greece has received very large sums that go towards cultural heritage. Many cultural institutions have been saved in Greece because of the work of the European Union," says Dennis Abbott, spokesman for Androulla Vassiliou, European Commissioner for culture and education. "But there are limits to what we can do. The main responsibility lies with the states," he says. -

\section{CORRECTION}

The News story 'Journal offers flat fee for "all you can publish"' (Nature 486, 166; 2012) stated that all co-authors on a paper must be members of PeerJ. In fact, only 12 co-authors need to be paying members. It also wrongly noted that $m B i o$ does not assess for impact or importance: it does. 